\title{
Pengembangan Board Game "Labyrinth in the Forest" Untuk Siswa Sekolah Menengah Pertama Materi Bilangan
}

\author{
Galih Kuat Prihandoko ${ }^{1}$, Tri Nova Hasti Yunianta ${ }^{2}$ \\ ${ }_{1,2}$ Program Studi Pendidikan Matematika, Fakultas Keguruan dan Ilmu Pendidikan, Universitas Kristen Satya Wacana, \\ Jl. Diponegoro 52-60 Kota Salatiga, Indonesia \\ 202017038@student.uksw.edu
}

\begin{abstract}
Attractive learning media can make the atmosphere in learning less boring, and it can improve learning outcomes. The development of learning media, namely the board game "Labyrinth in the Forest" for Junior High School (JHS) students, is needed and this is the purpose of this study. This type of development research uses the ADDIE development model. The subjects of this study used seven 7th grade students of JHS in Salatiga. The board game media was declared valid and practical with the percentage results of both $90 \%$ and $85 \%$ in the very good category. The significance result of the paired t-test is 0.000 (less than 0.005 ) supported by the posttest mean score higher than the pretest. The results of student responses stated that $96.5 \%$ chose the category very good or very practical to use. The conclusion of this study states that the media board game "Labyrinth in the Forest" that has been developed is valid, practical, and effective for the learning process, especially junior high school students on number material.
\end{abstract}

Keywords: board game, labyrinth, number, JHS

\begin{abstract}
Abstrak
Media pembelajaran yang menarik dapat membuat suasana dalam pembelajaran menjadi tidak membosankan, dan dapat meningkatkan hasil belajar. Pengembangan media pembelajaran yaitu board game "Labyrinth In the Forest" untuk siswa Sekolah Menengah Pertama (SMP) materi bilangan diperlukan dan inilah menjadi tujuan penelitian ini. Jenis penelitian pengembangan ini menggunakan model pengembangan ADDIE. Subjek penelitian ini menggunakan tujuh siswa kelas 7 SMP di Kota Salatiga. Media board game dinyatakan valid dan praktis dengan hasil persentase keduanya yaitu 90\% dan $85 \%$ dengan kategori sangat baik. Hasil signifikasi uji paired t-test adalah 0,000 (kurang dari 0,005) didukung dengan nilai rata-rata posttest lebih tinggi dibandingkan pretest. Hasil respons siswa menyatakan 96,5\% memilih dalam kategori sangat baik atau sangat praktis untuk digunakan. Simpulan penelitian ini menyatakan bahwa media board game "Labyrinth in the Forest" yang telah dikembangkan valid, praktis, dan efektif digunakan untuk proses pembelajaran khususnya siswa SMP pada materi bilangan.
\end{abstract}

Kata kunci: board game, labyrinth, bilangan, SMP

Copyright (c) 2021 Galih Kuat Prihandoko, Tri Nova Hasti Yunianta

$\triangle$ Corresponding author: Galih Kuat Prihandoko

Email Address: 202017038@student.uksw.edu (Jl. Diponegoro 52-60 Kota Salatiga, Indonesia)

Received 09 Maret 2021, Accepted 16 Maret 2021, Published 18 Maret 2021

\section{PENDAHULUAN}

Matematika memiliki konsep yang bersifat abstrak, menyebabkan siswa kesulitan untuk memahaminya (Rahmawati \& Lestari, 2018). Hal tersebut membuat suasana dalam pelajaran matematika menjadi bosan dan kesulitan (Hakim \& Windayana, 2016). Hal yang menyebabkan siswa merasa bosan dalam pembelajaran matematika adalah dengan diberikan soal-soal yang monoton. Listiani \& Prihatnani (2018) mengatakan penyebab siswa merasa bosan belajar karena diberikan soalsoal yang kurang menarik. Oleh sebab itu membuat matematika kurang disenangi siswa, sehingga siswa kesulitan untuk memahami bahkan mendapatkan nilai yang rendah (Hevriansyah \& Megawanti, 2017).

Penggunaan media pembelajaran merupakan cara yang dipakai oleh guru untuk memberikan pembelajaran dalam matematika menjadi menyenangkan. Sulistiani (2016) menyatakan bahwa dalam pembelajaran matematika diperlukan media yang sesuai, sehingga membuat suasana dalam 
Pengembangan Board Game "Labyrinth in the Forest" Untuk Siswa Sekolah Menengah Pertama Materi Bilangan, Galih

pembelajaran menjadi berkualitas. Menurut Setiyorini \& Abdullah (2013), media pembelajaran sebagai alat bantu guru untuk menyalurkan pesan supaya tercapainya tujuan pembelajaran. Maka dari itu, menggunakan media pembelajaran yang sesuai, diharapkan matematika dapat dimengerti, menarik, menyenangkan, dan dapat meningkatkan hasil belajar siswa.

Salah satu penggunaan media pembelajaran yang bisa digunakan dalam pembelajaran matematika yaitu board game. Board game terbukti sangat efektif untuk menyampaikan materi dalam pembelajaran (Listiani \& Prihatnani, 2018; Prasetyo, 2018). Selain efektif, board game juga dapat meningkatkan hasil belajar siswa (Ningrum \& Mariono, 2011; Novia, 2013; Irawan \& Wardani, 2016). Oleh karena itu, dengan bantuan media board game dalam pembelajaran, dapat berdampak terhadap hasil belajar siswa.

Board game (permainan papan) adalah alat-alat permainan yang ditempatkan, digerakan atau dipidahkan pada permukaan yang telah di tandai dengan aturan tertentu (Erlitasari \& Dewi, 2016). Menurut Limantara, Waluyanto \& Zacky (2015), keuntungan media board game antara lain dapat mengedukasi seseorang, membuat siswa untuk berinteraksi secara nyata, tidak seperti game online yang bersifat maya. Board game merupakan media yang dalam penyampaian informasi cukup baik secara persuasif dan juga dapat menciptakan interaksi secara langsung dengan orang lain (Wijaya, Wicandra \& Ashararianty, 2017). Hal ini dikarenakan media board game dapat dimainkan oleh berbagai kalangan usia dan permainannya menggunakan fitur sosial di antara permainannya (Najib \& Yuniarti, 2018).

Board game memiliki banyak jenis, beberapa diantaranya adalah Strategy game dan Trivia game. Menurut Bell, Strategy game adalah permainan yang menggunakan strategi-strategi dalam permainan dan ketrampilan dari permainannya untuk memenangkan permainan, sedangkan Trivia game adalah permainan yang menggunakan pengetahuan-pengetahuan umum pemainnya untuk menjalankan permainan (Limantara, Waluyanto \& Zacky, 2015; Wijaya, Tanudjaja \& Salamoon, 2013). Media pembelajaran yang memiliki strategi dan pengetahuan adalah board game "Labyrinth in the Forest" untuk siswa SMP kelas 7 pada materi bilangan.

Berdasarkan latar belakang di atas, penelitian pengembangan media pembelajaran diperlukan penelitian pengembangan media board game "Labyrinth in the Forest" untuk siswa Sekolah Menengah Pertama (SMP) materi bilangan dilakukan untuk memberikan bantuan kepada siswa dan diharapkan dengan media ini siswa dapat meningkatkan hasil belajar dan motivasi dalam belajar matematika. Melalui adanya media board game ini juga diharapkan guru dapat terbantu dalam menyediakan media pembelajaran berupa materi dan latihan soal yang menarik dan inovatif.

\section{METODE}

Penelitian ini tergolong dalam jenis penelitian pengembangan atau Research and Development $(\mathrm{R}$ \& D). Hasil akhir dalam penelitian ini yaitu media pembelajaran berupa board game yang bernama "Labyrinth in the Forest". Pengembangan media board game menggunakan model ADDIE yang didalam model ini memiliki lima tahapan penyelesaian untuk menghasilkan sebuah produk antara lain 
yaitu tahap analysis (analisis), tahap design (desain), tahap development (pengembangan), tahap implementation (implementasi), dan tahap evaluation (evaluasi).

Penelitian ini mengujicobakan media board game kepada tujuh siswa kelas 7 SMP. Media board game yang diujicobakan sebelumnya siswa telah mempelajari materi bilangan. Teknik pengumpulan data dalam penelitian ini berupa tes, non-tes, dan dokumentasi. Instrument yang digunakan dalam penelitian ini yaitu lembar penilaian kevalidan, lembar penilaian kepraktisan, lembar pendapat siswa, dan lembar soal pretest posttest. Instrument penelitian untuk menguji kevalidan, dan kepraktisan yaitu angket. Seluruh angket yang digunakan menggunakan 5 interval dalam skor penilaian antara lain 1 . sangat kurang, 2. kurang, 3. cukup, 4. baik, dan 5. sangat baik. Data angket dihitung menggunakan rumus: $P=\frac{S}{N} \times 100 \%$ dengan keterangan $\mathrm{S}$ : jumlah skor yang diperoleh dan N: jumlah skor maksimum. Persentase hasil data angket menentukan kategori penelitian media board game "Labyrinth in the Forest". Media dikatakan valid atau praktis jika dalam kategori minimal yaitu baik yang dapat dilihat pada Tabel 1 .

Tabel 1. Kriteria Kevalidan dan Kepraktisan

\begin{tabular}{|c|c|}
\hline Interval & keterangan \\
\hline $84 \% \leq$ skor $\leq 100 \%$ & Sangat baik \\
\hline $68 \% \leq$ skor $<84 \%$ & Baik \\
\hline $52 \% \leq$ skor $<68 \%$ & Cukup \\
\hline $36 \% \leq$ skor $<52 \%$ & Kurang \\
\hline $20 \% \leq$ skor $<36 \%$ & Sangat kurang \\
\hline
\end{tabular}

Sumber: (Abdullah \& Yunianta, 2018)

Hasil pretest dan posttest akan dianalisis untuk mengetahui keefektifan media board game. Hasil ujinya akan diolah menggunakan aplikasi SPSS pada taraf signifikan 5\%. Data akan diuji normalitasnya dengan menggunakan shapiro-wilk karena subjek yang digunakan kurang dari 30. Uji pair t-test akan digunakan saat uji normalitas terpenuhi dan uji wilcoxson akan digunakaan saat uji normalitas tidak terpenuhi. Media board game dikatakan efektif apabila hasil uji beda rerata kedua tesnya menghasilkan nilai signifikansi kurang dari 0,05 dan hasil rata-rata nilai posttest lebih tinggi dibandingkan nilai ratarata nilai pretest.

\section{HASIL DAN DISKUSI}

\section{Hasil Penelitian}

Penelitian ini menggembangkan sebuah media belajar yaitu board game "Labyrinth in the Forest" dengan menggunakan model penggembangan ADDIE. Pembuatan media board game "Labyrinth in the Forest" yaitu sebagai berikut:

\section{Analysis (Analisis)}

Pengembangan board game ini di awali dengan tahap analisis. Dalam tahap ini terdapat dua tahapan yang digunakan dalam penelitian ini yaitu analisis kebutuhan dan analisis kinerja. Analisis kebutuhan dilakukan untuk mengetahui media apa saja yang paling cocok saat digunakan pada 
Pengembangan Board Game "Labyrinth in the Forest” Untuk Siswa Sekolah Menengah Pertama Materi Bilangan, Galih Kuat Prihandoko ${ }^{1}$, Tri Nova Hasti Yunianta

pembelajaran matematika. Analisis kinerja dilakukan untuk mengguragi masaslah pada saat pembelajaran matematika. Hasil analisis menyimpulkan bahwa siswa merasa bosan terhadap kegiatan belajar yang monotoon maka dibutuhkan media pembelajaran yang sesuai untuk meningkatkan hasil belajar dan membuat tertarik terhadap pembelajaran matematika, salah satu media pembelajaran yaitu board game "Labyrinth in the Forest".

\section{Design (Desain)}

Setelah memperoleh rancangan media board game selanjutnya tahap desain. Tahap desain meliputi menyusun rancangan aturan, cara bermain dan komponen-komponen pendukung board game. Pembuatan komponen-komponen permainan didesain menggunakan aplikasi Corel Draw X7.

\section{Aturan Permainan}

Media board game "Labyrinth in the Forest" dimainkan secara berkelompok dengan tujuan siswa dapat berinteraksi terhadap siswa lain dalam satu kelompoknya. Suatu permainan membutuhkan peraturan dalam permaianan supaya board game ini dapat dimainkan secara efektif. Pada aturan permainan tidak hanya berisikan cara bermain saja tetapi juga terdapat penjelasan singkat tentang bagian tanpa karakter dan bagian dengan karakter. Desain aturan dan cara bermain dapat dilihat pada Gambar 1.

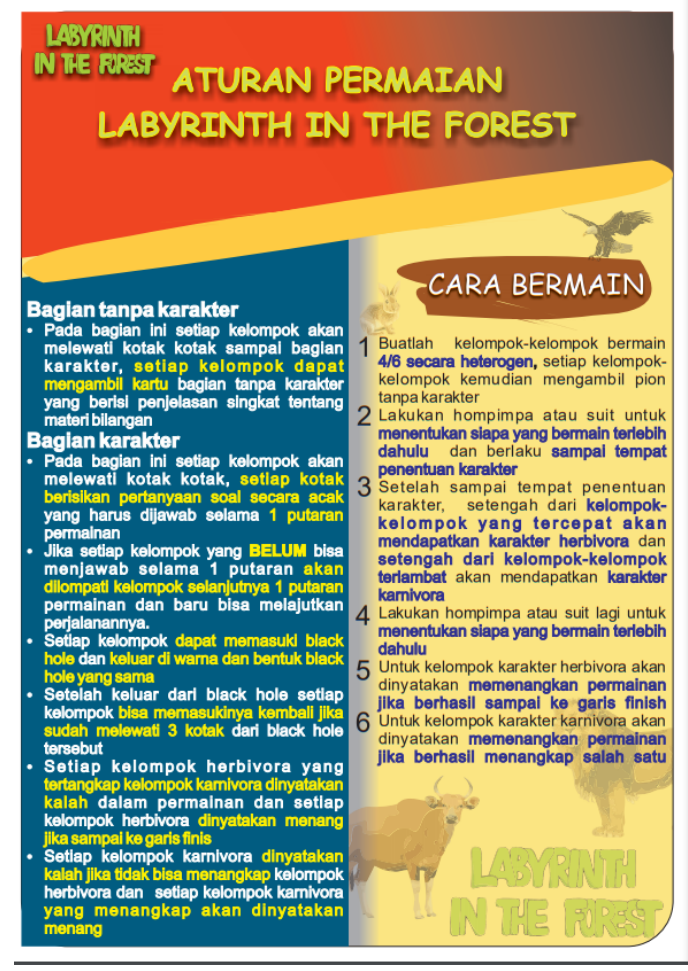

Gambar 1. Aturan dan Cara Bermain

\section{Desain Peta Permainan}

Setelah aturan dan cara bermain dibuat selanjutnya mendesain komponen-komponen pendukung media board game yaitu peta labirin, kartu permainan, dan pion. Peta labirin didesain berpetak dan bersekat sepanjang rute permainan, kemudian terdapat blackhole yang berlogo makanan herbivora dan 
karnivora yang dapat masuk dan keluar sesuai dengan makanannya. Bahan yang digunakan dalam pembuatan ini menggunakan kardus tebal (yellow board) dengan dilapisi stiker glossy dengan ukuran $60 \mathrm{~cm} \times 60 \mathrm{~cm}$ yang dapat dilihat pada Gambar 2.

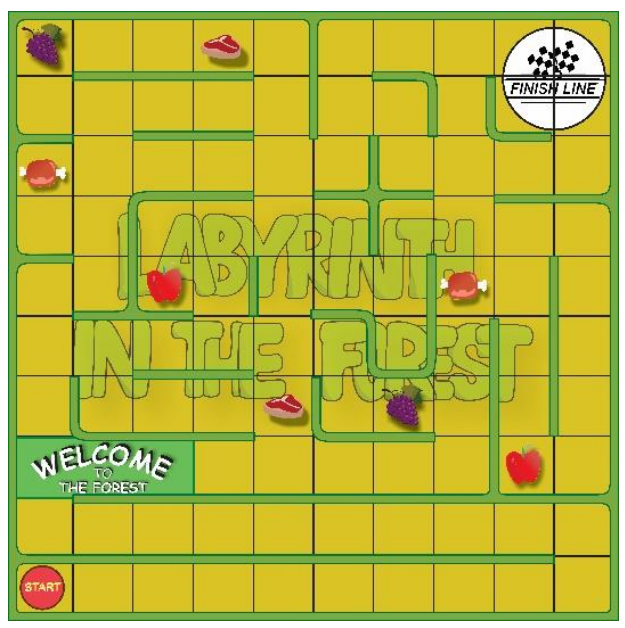

Gambar 2. Peta Labirin

\section{Desain Kartu Permainan}

Kartu permainan terdapat 2 bagian yaitu bagian depan dan bagian belakang dan terdapat 2 jenis kartu yaitu kartu materi dan kartu soal. Pada bagian belakang didesain dengan warna hijau dan biru dengan logo "Labyrinth in the Forest" untuk kartu materi dan kartu soal yang dapat dilihat pada Gambar 3. Desain bagian depan pada kartu materi terdapat ringkasan materi bilangan dan kartu soal terdapat latihan soal bilangan yang memiliki tingkat kesulitan yaitu LOTS, MOTS, dan HOTS dengan logo L, M, dan $\mathrm{H}$ pada bagian atas kartu soal. Bahan yang digunankan dalam pembuatan kartu permainan menggunakan kertas ivory 260 yang dilaminasi yang dapat dilihat pada Gambar 4 .

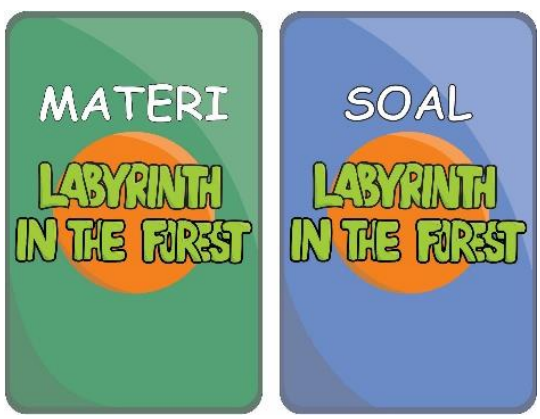

Gambar 3. Desain Kartu Bagian Belakang
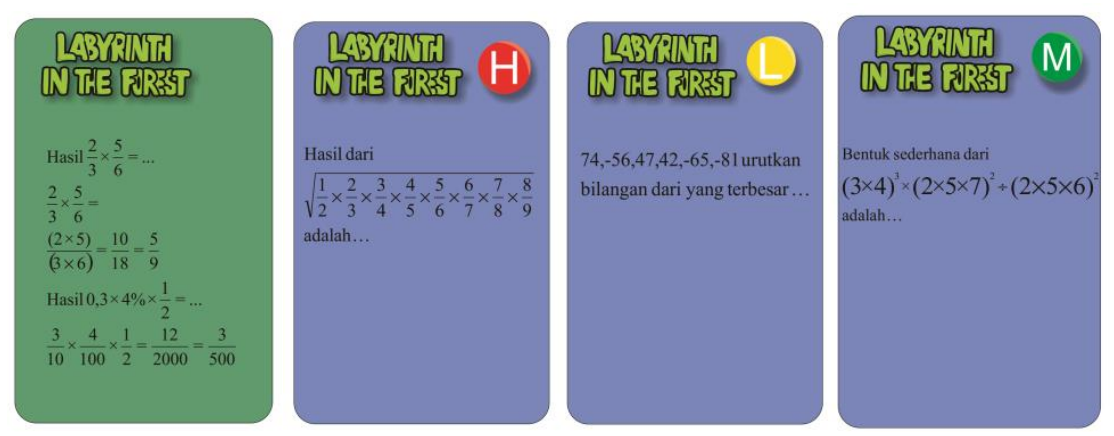

Gambar 4. Desain Kartu Bagian Depan 
Pengembangan Board Game "Labyrinth in the Forest” Untuk Siswa Sekolah Menengah Pertama Materi Bilangan, Galih Kuat Prihandoko ${ }^{1}$, Tri Nova Hasti Yunianta

\section{Desain Box Kartu Permainan}

Pembuatan tempat kartu menggunakan bahan yang sama dengan bahan kartu permainan. Desain box kartu permaian bagian depan bertemakan hutan dan bagian belakang terdapat logo "Labyrinth In the Forest" dan dibagian bawahnya terdapat gambar kartu permainan. Penggunaan warna dalam desain ini dengan perpaduan warna hijau dan biru. Desain dapat dilihat pada Gambar 5.

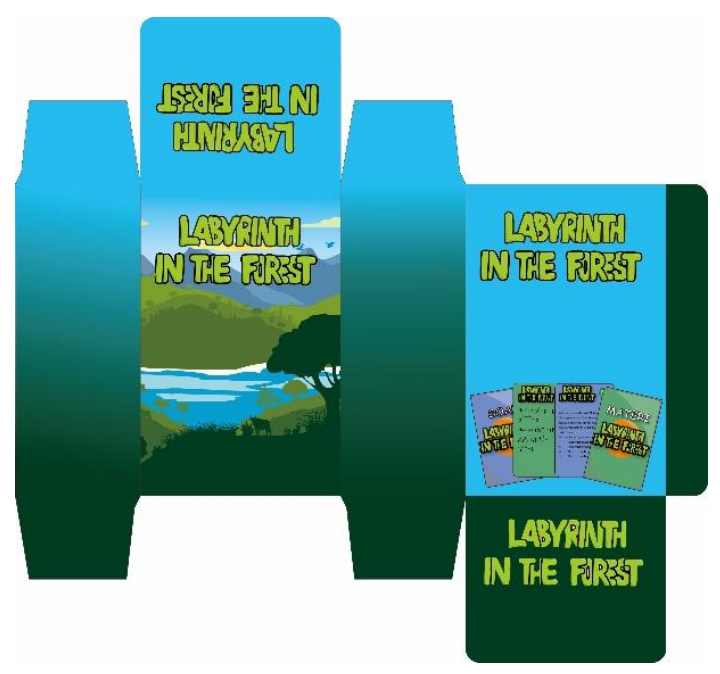

Gambar 5.

\section{Pion Permainan}

Pion didesain dengan bentuk segitiga sama kali dan menggunakan bahan dasar yellow board dengan dilapisi stiker glossy. Terdapat dua jenis pion yaitu pion tanpa karakter dan dengan karakter. Pion tanpa karakter hanya digunakan dari start sampai welcome sedangkan pion dengan karakter digunakan sesudah welcome. Karakter pada pion berupa karnivora (Singa, Harimau, dan Elang) dan herbivora (Banteng, Kelinci, dan Rusa). Desain pion dapat dilihat pada Gambar 6.

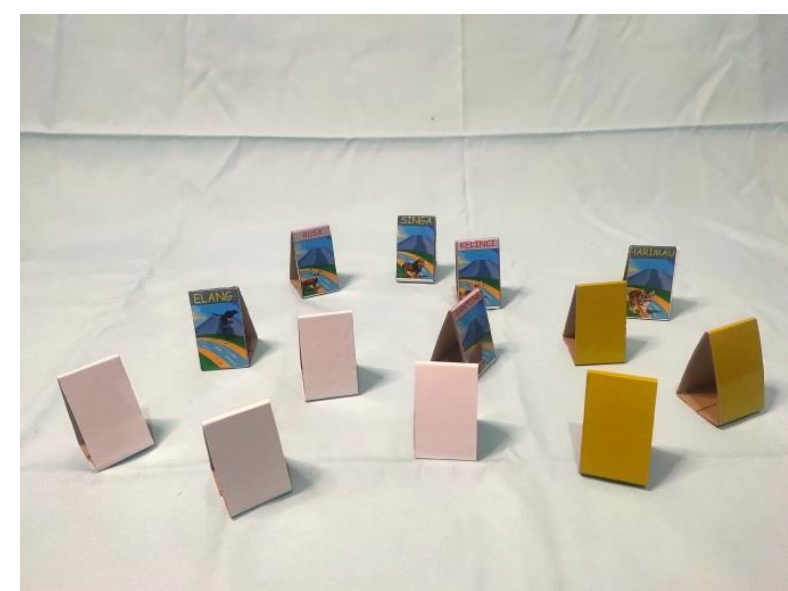

Gambar 6. Pion

\section{Kemasan Media}

Media board game dan komponen-komponen dikemas dalam satu kotak dengan bahan dasar yellow board dengan dilapisi stiker glossy dengan ukuran $41 \mathrm{~cm}$. Terdapat sekat pembatas didalam kemasan supaya tidak tercampur dengan komponen lainnya. Desan pada depan kemasan dibuat dengan sangat 
menarik dan menggunakan bahan yang tahan lama. Pengemasan media board game disajikan pada Gambar 7.

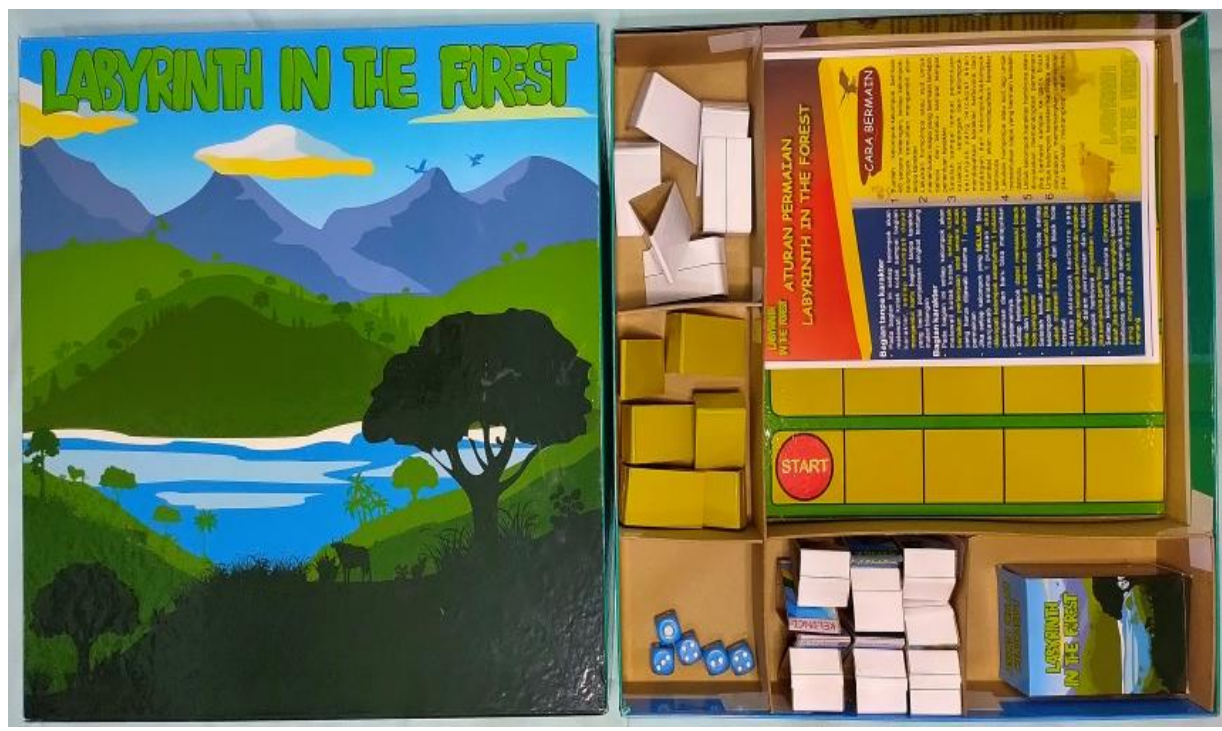

Gambar 7. Pengemasan Media

\section{Development (Pengembangan)}

Setelah semua desain sudah dibuat selanjutnya adalah memproduksi board game "Labyrinth In the Forest". Pemproduksian board game yang pertama yaitu mencetak peta permainan, pion, dan kemasan permainan. Komponen-komponen tersebut dicetak menggunakan bahan stiker glossy. Kedua, mencetak kartu permainan, kemasan kartu permaian dan aturan bermain menggunakan bahan ivory 260 yang dilaminasi agar media tahan lama dan tahan air. Ketiga membuat pola dan memotongnya sesuai dengan desain peta permainan, pion, dan kemasan permainan yang menggunakan bahan dasar berupa yellow board.

Media board game yang sudah selesai dibuat sebelum dilakuakan uji coba pada subjek penelitian, board game diukur kelayakannya dengan melakukan validasi. Board game akan divalidasi oleh ahli media dan ahli materi. Terdapat kritik maupun saran dari validator sebagai berikut: (a) terdapat pembahasan materi, soal, dan kunci jawaban yang salah; (b) terdapat cara bermain yang kurang cocok; (c) black hole diperbanyak dan sesuai karakter; dan (d) cover kemasan permainan kurang menarik. Berdasarkan kritik dan saran media board game direvisi dengan memperbaiki: (a) pembahasan materi, soal, dan kunci jawaban; (b) cara bermain menambahan pembagian kelompoknya secara heterogen; (c) memperbanyak black hole sesuai dengan makanan karakter; dan (d) mendesain ulang cover kemasan permainan yang lebih menarik.

\section{Implementation (Implementasi)}

Tahap berikutnya yaitu tahap implementasi. Board game ini telah diujicoba terhadap siswa kelas 7 di Salatiga. Sebelum diujicobakan board game harus dilakukan uji kevalidan media, uji kevalidan materi, dan uji kepraktisan. Angket uji kevalidan diisi oleh dua dosen yang ahli dalam bidang materi dan media. Berikut hasil uji kevalidan media dan materi yang dapat dilihat pada Tabel 2 dan Tabel 3. 
Tabel 2. Hasil Uji Kevalidan Media

\begin{tabular}{|c|c|c|}
\hline Aspek Penilaian & Persentase (\%) & Kategori \\
\hline Tampilan Umum & 92 & Sangat Baik \\
\hline Aturan Permainan & 94 & Sangat Baik \\
\hline Keekonomisan & 85 & Sangat Baik \\
\hline Penggunaan dan Pemeliharaan & 100 & Sangat Baik \\
\hline Rata-Rata & 92 & Sangat Baik \\
\hline
\end{tabular}

Tabel 3. Hasil Uji Kevalidan Materi

\begin{tabular}{|c|c|c|}
\hline Aspek Penilaian & Persentase (\%) & Kategori \\
\hline Kisi-Kisi Materi & 90 & Sangat Baik \\
\hline Soal & 92 & Sangat Baik \\
\hline Kontruksi & 83 & Baik \\
\hline Rata-Rata & 88 & Sangat Baik \\
\hline
\end{tabular}

Hasil dari uji kevalidan media dan materi memperoleh rata-rata $92 \%$ dan $88 \%$. Hasil tersebut menunjukan kategori sangat baik. Media board game dapat dikatakan valid pada bagian media dan materi.

Uji kepraktisan media berupa angket yang dilakukan oleh dua guru matematika SMP. Berikut hasil uji kepraktisan yang dapat dilihat pada Tabel 4.

Tabel 4. Hasil Uji Kepraktisan

\begin{tabular}{|c|c|c|}
\hline Aspek Penilaian & Presentase (\%) & Kategori \\
\hline Persiapan Pengguna & 90 & Baik \\
\hline Aturan Bermain & 80 & Baik \\
\hline $\begin{array}{c}\text { Kemudahan Cara } \\
\text { Bermain }\end{array}$ & 80 & Baik \\
\hline Interaksi Siswa & 90 & Sangat Baik \\
\hline Rata-Rata & 85 & Sangat Baik \\
\hline
\end{tabular}

Hasil uji kepraktisan menunjukan presentase sebesar 85\% termasuk dalam kategori sangat baik jadi media board game "Labyrinth in the Forest" dapat dikatakan sangat praktis untuk digunakan.

Board game "Labyrinth in the Forest" di ujicobakan pada bulan februari kepada siswa kelas 7 SMP sebanyak 7 siswa disekitar Kota Salatiga. Pada saat media board game "Labyrinth in the Forest" diujicobakan siswa sangat antusias terhadap media dan saling bersaing secara ketat untuk memenangkan board game "Labyrinth in the Forest".

\section{Evaluation (Evaluasi)}

Tahap terkahir dalam model ini adalah tahap evaluasi. Pada tahap ini terdapat uji keefektifan media yang bertujuan untuk mengevaluasi keberhasilan board game yang sudah dibuat dengan membandingkan hasil belajar siswa pada saat sebelum dan sesudah menggunakan media board game "Labyrinth in the Forest". Sebelum menggunakan media siswa diberikan tes awal (pretest). Kemudian siswa diajak belajar dan berlatih soal pada materi bilangan dengan menggunakan media board game "Labyrinth in the Forest". Setelah menggunakan media siswa mengerjakan tes yang kedua (posttest). 
Soal pretest dan soal posttest terdiri dari 10 butir soal pilihan ganda. Hasil pretest dan posttest akan dibandingkan dan mendapatkan hasil pada Tabel 5.

Tabel 5. Hasil Pretest dan posttest

\begin{tabular}{|c|c|c|c|c|c|}
\hline \multicolumn{6}{|c|}{ Descriptive Statistics } \\
\hline & $\mathrm{N}$ & Minimum & Maximum & Mean & Std. Deviation \\
\hline Pretest & 7 & 40 & 90 & 61.43 & 19.518 \\
\hline Posttest & 7 & 60 & 100 & 82.86 & 14.960 \\
\hline $\begin{array}{l}\text { Valid N } \\
\text { (listwise) }\end{array}$ & 7 & & & & \\
\hline
\end{tabular}

Guna untuk menggetahui keefektifan media board game "Labyrinth in the Forest" maka diperlukannya uji beda rerata antara hasil pretest dan posttest. Pertama-tama dilakukan uji normalitas data yang hasil uji normalitasnya dapat dilihat pada Tabel 6 .

Tabel 6. Hasil Uji Normalitas

\begin{tabular}{|l|r|r|r|r|r|r|}
\hline \multicolumn{1}{|c|}{ Tests of Normality } \\
\hline & \multicolumn{2}{|c|}{ Kolmogorov-Smirnov ${ }^{\mathrm{a}}$} & \multicolumn{3}{c|}{ Shapiro-Wilk } \\
\cline { 2 - 7 } & Statistic & df & \multicolumn{1}{c|}{ Sig. } & \multicolumn{1}{c|}{ Statistic } & df & \multicolumn{1}{c|}{ Sig. } \\
\hline Pretest & .150 & 7 & $.200^{*}$ & .930 & 7 & .549 \\
\hline Posttest & .160 & 7 & $.200^{*}$ & .935 & 7 & .591 \\
\hline *. This is a lower bound of the true significance. \\
3. Lilliefors Significance Correction \\
\hline
\end{tabular}

Pada Tabel 6 uji normalitas yang dapat dilihat hanya pada kolom Shapiro-Wilk, karena subjek yang digunakan kurang dari 30. Hasil uji tersebut menunjukan nilai signifikan dari pretest dan posttest sebesar 0,549 dan 0,591 yang hasil keduanya lebih besar dari 5\%. Dari data tersebut menujukan nilai dari kedua tes tersebut dari populasi berdistribusi normal. Setelah hasil uji berdistribusi normal maka uji beda rerata dapat dilakukan dengan menggunakan uji Paired t-Test. Hasil uji Paired t-Test dapat dilihat pada Tabel 7.

Tabel 7. Hasil Uji Paired t-Test

\begin{tabular}{|c|c|c|c|c|c|c|c|c|c|}
\hline \multicolumn{10}{|c|}{ Paired Samples Test } \\
\hline & & \multicolumn{5}{|c|}{ Paired Differences } & \multirow[t]{3}{*}{$\mathrm{t}$} & \multirow[t]{3}{*}{$\mathrm{df}$} & \multirow{3}{*}{$\begin{array}{l}\text { Sig. (2- } \\
\text { tailed) }\end{array}$} \\
\hline & & \multirow[t]{2}{*}{ Mean } & \multirow[t]{2}{*}{$\begin{array}{c}\text { Std. } \\
\text { Deviation }\end{array}$} & \multirow[t]{2}{*}{$\begin{array}{c}\text { Std. Error } \\
\text { Mean }\end{array}$} & \multicolumn{2}{|c|}{$\begin{array}{c}\text { 95\% Confidence } \\
\text { Interval of the } \\
\text { Difference }\end{array}$} & & & \\
\hline & & & & & Lower & Upper & & & \\
\hline $\begin{array}{l}\text { Pair } \\
1\end{array}$ & Posttest-Pretest & 21.429 & 6.901 & 2.608 & 15.047 & 27.811 & 8.216 & 6 & .000 \\
\hline
\end{tabular}

Hasil uji Paired $t$-Test menunjukan bahwa nilai signifikan yaitu 0,000 kurang dari 5\% sehingga data 
tersebut menunjukan beda yang signifikan. Media board game "Labyrinth in the Forest" dapat dinyatakan efektif untuk digunakan. Penelitian ini juga menggunakan data kualitatif pendapat siswa yang digunakan untuk mengetahui respon siswa terhadap penggunaan media board game "Labyrinth in the Forest". Hasil lebar pendapat siswa dapat lihat pada Tabel 8.

Tabel 8. Hasil Lembar Pendapat Siswa

\begin{tabular}{|c|c|c|}
\hline Aspek Penilaian & Persentase (\%) & Kategori \\
\hline $\begin{array}{c}\text { Memudahakan belajar } \\
\text { matematika }\end{array}$ & 97 & Sangat Baik \\
\hline Menumbuhkan interaksi siswa & 97 & Sangat Baik \\
\hline $\begin{array}{c}\text { Media digunakan pada materi } \\
\text { matematika yang lain }\end{array}$ & 97 & Sangat Baik \\
\hline Tampilan yang menarik & 97 & Sangat Baik \\
\hline Permainan yang menantang & 94 & Sangat Baik \\
\hline Ketertarikan proses bermain & 97 & Sangat Baik \\
\hline Rata-rata & 96,5 & Sangat Baik \\
\hline
\end{tabular}

Berdasarkan hasil pendapat siswa menghasilkan rata-rata 96,5\% dalam kategori sangat baik. Dari hasil tersebut dapat disimpulkan bahwa media board game "Labyrinth in the Forest" sangat praktis untuk digunakan.

\section{Pembahasan}

Setelah melakukan pengembangan media menggunakan model ADDIE mendapatkan sebuah produk board game "Labyrinth in the Forest". Media board game ini berisikan ringkasan materi dan soal yang memiliki tingkatan kesulitan soal yang berbeda. Ketika memainkan media board game ini memerlukan strategi dan pengetahuan umum pemain untuk memenangkan permaian ini.

Media board game sebelum digunakan pada siswa harus melewati tahap-tahap pengujian terlebih dahulu yang pertama pengujian kevalidan. Uji kevalidan media board game ini mendapatkan rata-rata penilaian sebesar $92 \%$ untuk media dan $88 \%$ untuk materi keduanya mendapatkan kategori sangat baik. Kedua uji kepraktisan mendapatkan rata-rata $85 \%$ yang dalam kategori sangat baik. Dari hasil kevalidan dan kepraktidan media board game "Labyrinth in the Forest" dapat dikatakan media yang valid dan praktis.

Setelah media dinyatakan valid dan praktis media dapat diujicobakan terhadap siswa untuk mengetahui keefektifan media tersebut. Pretest dan posttest digunakan untuk mengetahui perbedaan hasil belajar siswa sebelum dan sesudah menggunakan media board game dengan menggunakan uji pair t-test. Hasil uji pair t-test menunjukan signifikan 0,000 kurang dari 5\% yang artinya terdapat perbedaan. Rata-rata hasil uji kedua tesnya adalah 61,43 dan 82,86 maka terdapat peningkatan hasil belajar. Dari hasil data yang diperoleh maka media board game "Labyrinth in the Forest" dinyatakan efektif untuk digunakan. Siswa juga dapat berpendapat tentang media board game ini dengan menggunakan lembar pendapat siswa. Hasil pendapat siswa mendapatkan rata-rata 96,5\% yang termasuk dalam kategori sangat baik sehingga dinyatakan praktis digunakan. Penelitian ini juga sejalan 
dengan Prambudi \& Yunianta (2020) dengan pengembangan board game bus race algebra yang terbukti valid, praktis, dan efektif digunakan sebagai sarana latihan soal aljabar bagi siswa kelas 7 SMP. Selain itu terdapat penelitian lain yang serupa yaitu penelitian dari Andini \& Yunianta (2018) dan Triastuti, Akbar \& Irawan (2017) media board game yang terbukti valid, praktis, dan efektif digunakan untuk sarana pembelajaran.

Media board game "Labyrinth in the Forest" ini tidak hanya meningkatkan hasil pembelajaran tetapi juga berinterakasi sosial dan meningkatkan motivasi belajar. Hal ini sependapat dengan Latief (2017) dan Prambudi \& Yunianta (2020) yang menyatakan media board game mampu menumbuhkan interaksi sosial yang menciptakan lingkungan belajar tidak membosankan dan meningkatkan motivasi belajar siswa.

\section{KESIMPULAN}

Penelitian pengembangan ini menghasilkan sebuah produk berupa media belajar yaitu board game "Labyrinth in the Forest" untuk siswa kelas 7 SMP khususnya pada materi bilangan. Berdasarkan hasil penelitian dapat disimpulkan bahwa media board game ini dinyatakan valid, praktis, dan efektif untuk digunakan sebagai sarana pembelajaran matematika terutama pada materi bilangan. Selain itu media board game ini dapat dikembangkan lagi dengan materi yang lain maupun dengan mata pelajaran yang lain karena model kartu permaian yang dapat diganti sesuai dengan kebutuhan. Namun dalam mengembangkan media board game ini, hal yang perlu diperhatikan yaitu pemilihan soal latihan yang dapat dikerjakan dalam waktu yang cepat, tepat, dan cermat. Hal tersebut supaya saat menggunakan media board game tidak membutuhkan waktu pengerjaan yang lama.

\section{UCAPAN TERIMA KASIH}

Peneliti berterimaksih kepada Rektor Universitas Kristen Satya Wacana, Dekan FKIP UKSW, Kaprogdi Pendidikan Matematika, Dosen Pembimbing, Siswa SMP, dan seluruh pihak yang telah membantu dalam pelaksanaan kegiatan ini, sehingga terlakasana dengan baik.

\section{REFERENSI}

Abdullah, F. S., \& Yunianta, T. N. H. (2018). Pengembangan Media Pembelajaran Matematika Trigo Fun Berbasis Game Edukasi Menggunakan Adobe Animate Pada Materi Trigonometri. AKSIOMA: Jurnal Program Studi Pendidikan Matematika, 7(3), 434. https://doi.org/10.24127/ajpm.v7i3.1586

Andini, M., \& Yunianta, T. N. H. (2018). The Development of Borad game "The Adventure Of Algebra" in The Senior High School Mathematics Learning. Al-Jabar: Jurnal Pendidikan Matematika, 9(2), 95-109. https://doi.org/10.24042/ajpm.v9i2.3424

Erlitasari, N. D., \& Dewi, U. (2016). Nova Dwi Erlitasari. Jurnal Mahasiswa Teknologi Pendidikan, $7(1), 1-12$. 
Hakim, A. R., \& Windayana, H. (2016). Pengaruh Penggunaan Multimedia Interaktif Dalam Pembelajaran Matematika Untuk Meningkatkan Hasil Belajar Siswa SD. EduHumaniora|Jurnal Pendidikan Dasar Kampus Cibiru, 4(2). https://doi.org/10.17509/eh.v4i2.2827

Hevriansyah, P., \& Megawanti, P. (2017). Pengaruh Kemampuan Awal terhadap Hasil Belajar Matematika. JKPM (Jurnal Kajian Pendidikan Matematika), 2(1), 37. https://doi.org/10.30998/jkpm.v2i1.1893

Latief, M. (2017). Pengembangan Permainan Ular Jarra Sebagai Media Pembelajaran Pada Materi Pokok Asam-Basa. Jurnal Penelitian Pendidikan INSANI, 20(2), 101-107.

Limantara, D., Waluyanto, H. D., \& Zacky, A. (2015). Perancangan Board game Untuk Menumbuhkan Nilai-Nilai Moral Pada Remaja. 1-9. publication.petra.ac.id

Listiani, D., \& Prihatnani, E. (2018). Pengembangan media pembelajaran dart board math bagi siswa kelas VII SMP. Math Didactic: Jurnal Pendidikan Matematika, 4(1), 21-33. https://doi.org/10.33654/math.v4i1.80

Media, P., Permainan, P., Tangga, U., Dan, S., Untuk, J., Hasil, M., Matematika, B., Iv, K., Mi, D. I., Tholibin, J., Tarbiyah, F., Islam, U., Maulana, N., \& Malang, I. (2013). Oleh : Lely Gusliana Novia NIM. 09140074.

Najib, A., \& Yuniarti, N. (2018). Pengembangan Media Pembelajaran Board Game Berbasis Augmented Reality Pada Mata Pelajaran the Development of Learning Media on Augmented Reality Board. Pendidikan Teknik Mekatronika, 8 No. 1(3), 9-19.

Ningrum, S. S., Pendidikan, T., Pendidikan, F. I., \& Surabaya, U. N. (2011). Pengembangan Media Visual Papan Permainan Pada Materi Bentuk.

Prambudi, E. Y., \& Yunianta, T. N. H. (2020). Pengembangan Media Bus Race Algebra Pada Materi Bentuk Aljabar Untuk Siswa Kelas VII SMP. Jurnal Cendekia : Jurnal Pendidikan Matematika, 4(1), 8-22. https://doi.org/10.31004/cendekia.v4i1.150

Prasetyo, M. F. (2018). Persamaan Garis Lurus Bagi Siswa Kelas Viii Smp Negeri. 5(1), 14-26. Rahmawati, H., \& Lestari, W. M. (2018). PENGGUNAAN MEDIA PAPAN MAGNET UNTUK DIDIK KELAS II SDN TANJEK WAGIR KECAMATAN KREMBUNG TAHUN 2018. 1(1).

Setiyorini, I., \& Abdullah, M. H. (2013). Penggunaan Media Permainan Kartu Kuartet Pada Mata Pelajaran IPS Untuk Peningkatan Hasil Belajar Siswa di Sekolah Dasar. Jurnal Penelitian Pendidikan Guru Sekolah Dasar, 1 (2), 1-10.

Sulistiani, I. R. (2016). Pembelajaran Matematika Materi Perkalian Dengan Menggunakan Media Benda Konkret (Manik -Manik Dan Sedotan) Untuk Meningkatkan Hasil Belajar. VICRATINA : Jurnal Kependidikan $\quad$ Dan 22-23. http://riset.unisma.ac.id/index.php/fai/article/view/166

Triastuti, D., Akbar, S., \& Irawan, E. B. (2017). Pengembangan Media Papan Permainan Panjat Pinang. Jurnal Pendidikan, 2(10), 1344-1350.

Wardani, andi irawan dan melda ayu. (n.d.). ( Improving the Result of Learning Mathematics By Using 
the. $342-348$.

Wijaya, B., Wicandra, O. B., \& Asthararianty. (2017). Perancangan Board Game Sebagai Media Pembelajaran Manfaat Sayuran Untuk Kesehatan Bagi Anak Usia 6-8 Tahun. Jurnal DKV Adiwarna, Universitas Kristen Petra, 1(1), 1-8.

Wijaya, N. M., Bedjo Tanudjaja, B., \& Salamoon, D. K. (2013). Perancangan Board Game Pembelajaran Sopan Santun Untuk Anak Usia 6-10 Tahun. Perancangan Board Game Pembelajaran Sopan Santun Untuk Anak Usia 6-10 Tahun, 1-10. https://media.neliti.com/media/publications/87287-ID-none.pdf 